Original Research Paper

\title{
Heterologous Expression and Biochemical Characterization of Lipase from Burkholderia cepacia Lu10-1
}

\author{
${ }^{1,2,3}$ Yao Zhang, ${ }^{1,2}$ Lu Wang and ${ }^{1,2}$ Yuanda Song \\ ${ }^{I}$ Colin Ratledge Center for Microbial Lipids, School of Agricultural Engineering and Food Science, \\ Shandong University of Technology, 266 Xincun West Road, Zibo 255000, People's Republic of China \\ ${ }^{2}$ Key Laboratory of Shandong Provincial, Universities for Technologies in Functional Agricultural Products, \\ Shandong University of Technology, 266 Xincun West Road, Zibo 255000, People's Republic of China \\ ${ }^{3}$ College of Life Science, Shandong Agricultural University, 61 Daizong Street, Taian 271018, People's Republic of China
}

Article history

Received: 17-10-2017

Revised: $13-12-2017$

Accepted: 23-12-2017

Corresponding Author: Colin Ratledge Center for Microbial Lipids, School of Agricultural Engineering and Food Science, Shandong University of Technology, 266 Xincun West Road, Zibo 255000, People's Republic of China

Email: 1z20011022@126.com ysong@sdut.edu.cn Yao Zhang and Yuanda Song

\begin{abstract}
Even though lipase genes from a variety of microorganism have been cloned and over-expressed, the prospective lipase resources for commercial production and industry application are still limited. In the present study, a lipase from Burkholderia cepacia Lu10-1 is heterologously over-expressed in Escherichia coli strain BL21(DE3) and purified to homogeneity. The molecular weight of the recombinant lipase from B. cepacia Lu10-1 (abbreviated as lipase Lu10-1) is estimated to be about $33 \mathrm{kDa}$ by SDS-PAGE. The lipase Lu10-1 has a priority for the long- chain length substrates. The optimal temperature of lipase Lu10-1 is $60^{\circ} \mathrm{C}$ and it preserves high thermostability with residual activities of over $80 \%$ after $100 \mathrm{~h}$ at $60^{\circ} \mathrm{C}$ or over $60 \%$ after $30 \mathrm{~h}$ at $70^{\circ} \mathrm{C}$. The optimal $\mathrm{pH}$ of lipase Lu10-1 is 9.0 and it has broad $\mathrm{pH}$ adaptability over a range of 5.0-10.0 retaining $80 \%$ activity between $\mathrm{pH} 6.0$ and 9.0 after incubation at $37^{\circ} \mathrm{C}$ for $24 \mathrm{~h}$. Moreover, the enzymatic activity of lipase Lu10-1 is not obviously affected by several metal ions and it exhibites solid tolerance and stability towards various surfactants and organic solvents. The present study provides the basis for the potential applications of lipase Lu10-1 in related industries.
\end{abstract}

Keywords: Lipase, Burkholderia cepacia, Escherichia coli, Expression, Characterization

\section{Introduction}

Lipase, or triacylglycerol acylhydrolase (EC 3.1.1.3) can not only hydrolyze glycerol at the oil-water interface and ester bonds of triglycerides, but also catalyze transesterification and ester synthesis. In view of a variety of functions, lipase has commercial values in detergent, food textile, paper, cosmetics, leather tanning, biofuel and bioremediation, etc (Fickers et al., 2011; Garcia-Silvera et al., 2017; Jaeger et al., 1999). Although a lot of lipases can be separated from plants or animals, recently, because of their versatile catalytic capacity, particular biochemical property, high production and simplicity of gene manipulation, more and more research was focused on microbial lipases (Sangeetha et al., 2011; Singh and Mukhopadhyay, 2012).

It has been reported that the lipase from Burkholderia (previously Pseudomonas) cepacia possesses attractive particular interest due to its high thermostability and strong tolerance to organic solvents (Jia et al., 2010;
Mello Bueno et al., 2015; Sasso et al., 2016), therefore, different kinds of Burkholderia lipase genes have been cloned and over-expressed in heterogonous or homologous hosts (Jia et al., 2010; Shu et al., 2016; Wang et al., 2009; Xie et al., 2016; Yang et al., 2007). However, the high yield of the active forms in heterogonous host such as Escherichia coli has not yet been achieved. The main reason is that most of lipase proteins exist in the cell periplasmic space in the form of inactive inclusion bodies and the refolding procedure is request to obtain the active proteins, which limits the lipase for large-scale industrial application.

In the present study, a lipase from bacterium $B$. cepacia strain Lu 10-1 (GenBank, EF546394) was successfully cloned and over-expressed in E. coli as a secreted protein. In addition, the recombinant enzyme was purified to homogeneity and its enzymatic properties were also investigated in detail. This study would provide the basis for industry application of the recombinant lipase Lu10-1. 


\section{Materials and Methods}

\section{Baterial Strain, Plasmids and Chemicals}

A novel strain of $B$. cepacia Lu 10-1 possessing wellestablished lipase activity was previously isolated and identified by $16 \mathrm{~S}$ rRNA gene sequencing (GenBank EF546394) in our lab (Ji et al., 2010). The plasmid pMD18T and E. coli JM109 were used for gene cloning. The plamid pET20b(+) and E. coli BL21(DE3) were used for heterologous expression in E. coli.

\section{Medium and Culture Conditions}

Luria-Bertani (LB) medium, containing peptone 10 $\mathrm{g} / \mathrm{l}$, yeast powder $5 \mathrm{~g} / \mathrm{L}, \mathrm{NaCl} 10 \mathrm{~g} / \mathrm{L}, \mathrm{pH} 7.1$, was used for seed medium. The fermentation medium contained glucose $6 \mathrm{~g} / \mathrm{L}$, peptone $12 \mathrm{~g} / \mathrm{L}$, yeast powder $24 \mathrm{~g} / \mathrm{L}$, $\mathrm{K}_{2} \mathrm{HPO}_{4} 3 \mathrm{H}_{2} \mathrm{O} 16.43 \mathrm{~g} / \mathrm{L}, \mathrm{KH}_{2} \mathrm{PO}_{4} 2.31 \mathrm{~g} / \mathrm{L}, \mathrm{pH}$ 7.1. E. coli cells were grown in LB medium at $37^{\circ} \mathrm{C}$ and ampicillin was added to the medium with a final concentration of $100 \mu \mathrm{g} / \mathrm{mL}$.

\section{Gene Cloning of Lipase Lu10-1}

The lipase Lu10-1 was isolated by PCR amplification from the genome of $B$. cepacia Lu10-1 with the forward primer (5'-3': GGAATACCATATGTCCATGGCC GCTGGCTACGCGGCGA) and the reverse primer (5'3': CATCTCGAGAGAATTC GGTTACACGCCCGCCAGCTTCAGCCG) that introduced the $N c o$ I and EcoR1 restriction sites at the 5'and 3'- ends, respectively. The PCR procedure was progressed by 35 successive cycles as follows: denaturation at $94^{\circ} \mathrm{C}$ for $30 \mathrm{sec}$, annealing at $56^{\circ} \mathrm{C}$ for 60 sec and extension at $72^{\circ} \mathrm{C}$ for $120 \mathrm{sec}$. Following the PCR, this gene is subsequently ligated into two different vectors, pMD18T-simple and pET20b(+), using Ncol and EcoR1 sites and the successful insertion of the gene was confirmed by restriction digestion and DNA sequencing. The plasmids with the correct sequence for lipase Lu10-1 were named pMD18T/lip and pET20b/lip, respectively.

\section{Expression and Purification of Lipase Lu10-1}

E. coli BL21(DE3) harboring the plasmid pET20b/lip was inoculated into $50 \mathrm{~mL}$ of seed medium with 100 $\mu \mathrm{g} / \mathrm{mL}$ ampicillin at $200 \mathrm{rpm}$ and $37^{\circ} \mathrm{C}$ for $8 \mathrm{~h}$. A $5 \%$ $(\mathrm{v} / \mathrm{v})$ inoculum was inoculated into $100 \mathrm{~mL}$ fermentation medium (contaning $100 \mu \mathrm{g} / \mathrm{mL}$ ampicillin) at $200 \mathrm{rpm}$ and $30^{\circ} \mathrm{C}$. When the optical density at $600 \mathrm{~nm}\left(\mathrm{OD}_{600}\right)$ of the culture reached at about 1.5 to 2.0 , the inducer Isopropyl-1-thio- $\beta$-D-galactopyranoside (IPTG) was added in a final concentration of $0.5 \mathrm{mM}$. Then, after 18 $\mathrm{h}$ of induction, the culture was centrifuged $(10,000 \times \mathrm{g}$, $30 \mathrm{~min}, 4^{\circ} \mathrm{C}$ ) and the supernatant and cells were collected, respectively. The cells were broken by ultrasonic waves. Supernatant and cell fractions (soluble and insoluble cytoplasm) were suspended for protein detection using SDS-PAGE.
$70 \%(\mathrm{w} / \mathrm{v})$ saturated ammonium sulphate solution was added to the supernatant abovementioned and then the solution was kept at $4^{\circ} \mathrm{C}$ for $12 \mathrm{~h}$. Precipitates were centrifugal collected and dissolved in $100 \mathrm{~mL}$ buffer A (20 $\mathrm{mM}$ imidazole, $20 \mathrm{mM}$ sodium phosphate and $0.5 \mathrm{M}$ $\mathrm{NaCl}, \mathrm{pH}$ 7.4). Subsequently, the above solutions were dialyzed by 21 of equal buffer A for $12 \mathrm{~h}$ and employed to a nickel affinity column. The column was pre-equilibrated with buffer A for 2 column volumes and then samples were loaded to bind Ni-NTA with a flow rate of $1 \mathrm{~mL} / \mathrm{min}$. Washing elution with buffer A was followed while reaching the UV baseline. A linear gradient from 0 to 500 $\mathrm{mM}$ imidazole in buffer A was continued to wash by 2 column volumes. The collected fractions which included $p$ NPP lipase activity were assembled and dialyzed by 21 of buffer $\mathrm{B}(20 \mathrm{mM}$ Tris- $\mathrm{HCl}, \mathrm{pH} 8.0)$ at $4^{\circ} \mathrm{C}$ for $12 \mathrm{~h}$. The purified lipase was finally concentrated by ultrafiltration and stored at $-80^{\circ} \mathrm{C}$.

\section{Determination of Bacteria Biomass}

The optical density of the culture at $600 \mathrm{~nm}\left(\mathrm{OD}_{600}\right)$ during cultivation which represented the bacterial biomass was monitored by a spectrophotometer.

\section{Lipase Activity Assay}

Lipase activity was estimated as previously described (Gricajeva et al., 2016), utilizing $p$-Nitrophenyl palmitate ( $p$-NPP) as substrate. The mixture solution $(100.0 \mathrm{~mL})$ containing $1 \mathrm{~mL}$ of $p$-NPP $(10 \mathrm{mM}), 4 \mathrm{~mL}$ of absolute ethanol and $95 \mathrm{~mL}$ of Tris- $\mathrm{HCl}(50 \mathrm{mM})$ was prepared and stored at $-20^{\circ} \mathrm{C}$. A $4 \mathrm{~mL}$ above solution was incubated with $0.1 \mathrm{~mL}$ of appropriately diluted enzyme for $15 \mathrm{~min}$ at $40^{\circ} \mathrm{C}$. The reaction was immediately stopped by ice bath.

The activity against $p$-Nitrophenyl butyrate ( $p$ NPB) with minor revision was determined as previously reported (Chen et al., 2008; Zhang et al., 2010). A final volume of $1 \mathrm{~mL}$ mixture solution containing $p$ NPB (1 $\mathrm{mM})$ and the assay buffer $(50 \mathrm{mM}$ sodium taurodeoxycholate, $10 \mathrm{mM} \mathrm{NaCl}$ and $50 \mathrm{mM}$ Tris- $\mathrm{HCl}$, $\mathrm{pH}$ 8.0) was incubated $0.02 \mathrm{~mL}$ appropriately diluted enzyme for $1 \mathrm{~min}$ at $40^{\circ} \mathrm{C}$.

The hydrolysis of $p$ NPP and $p$ NPB for the formation of $p \mathrm{NP}$ was monitored at $410 \mathrm{~nm}$ by a UV-vis spectrophotometer. One unit of enzyme activity was defined as the amount of enzyme that catalyzed the substrate and liberated $1 \mu \mathrm{mol}$ of $p$-nitrophernol $(p \mathrm{NP})$ per min at $\mathrm{pH} 8.0$ and $40^{\circ} \mathrm{C}$. The experiments and their blank control were repeated in triplicate.

The activity towards triolein or tributyrin was measured as previously reported (Jaeger et al., 1994) with some modifications. Triolein or tributyrin emulsion was prepared by emulsifying triolein/tributyrin and $0.5 \%$ (w/v) gum arabic in $25 \mathrm{mM}$ potassium phosphate buffer $(\mathrm{pH} 9)$ for $10 \mathrm{~min}$ in high-speed tissue crusher. The 
reaction solution containing $2.5 \mathrm{~mL}$ of $25 \mathrm{mM}$ potassium phosphate buffer ( $\mathrm{pH} 9$ ) and $2 \mathrm{~mL}$ of emulsion and enzyme was incubated for $15 \mathrm{~min}$ and then finished by adding $7.5 \mathrm{~mL}$ of ethanol. The determination of released fatty acids was performed by titration with $2 \mathrm{M} \mathrm{NaOH}$. One unit of lipase acitivity was defined as the amount of enzyme that released $1 \mu \mathrm{mol}$ of fatty acid per min at $\mathrm{pH}$ 9.0 and $40^{\circ} \mathrm{C}$. The experiments and their blank control were repeated in triplicate.

\section{Temperature Optimum and Thermostability}

Temperature optima of the recombinant lipase Lu101 was surveyed at temperatures ranging from 35 to $80^{\circ} \mathrm{C}$. The enzyme activity was determined by pre-incubating the reaction buffer $[50 \mathrm{mM}$ sodium taurodeoxycholate, $10 \mathrm{mM} \mathrm{NaCl}$ and $20 \mathrm{mM}$ Tris-HCl, $\mathrm{pH}$ 9.0] with $p \mathrm{NPP}$ as substrates at different temperature for $5 \mathrm{~min}$. The determination of enzyme thermostability was performed in Tris- $\mathrm{HCl}(20 \mathrm{mM}, \mathrm{pH} 9.0)$ at the various temperatures $\left(50-80^{\circ} \mathrm{C}\right)$ with enzymes. Samples were removed and measured for their residual activity with $p$ NPP as substrate at different intervals. The experiments were repeated in triplicate.

\section{pH Optimum and Stability}

$\mathrm{pH}$ optima of the recombinant lipase Lu10-1 was investigated at a $\mathrm{pH}$ range of 6.0 to 10.0 by using potassium phospate buffer ( $\mathrm{pH}$ 6.0-7.0), Tris-HCl buffer (7.0-9.0) and sodium carbonate buffer ( $\mathrm{pH} 9.0-10.0)$, respectively. $\mathrm{pH}$ stability was determined in the following buffers with the concentration of $20 \mathrm{mM}$ : sodium acetate ( $\mathrm{pH} 4.0-6.0)$, potassium phospate $(\mathrm{pH} 6.0-7.0)$, Tris- $\mathrm{HCl}$ (pH 7.0-9.0) and glycine- $\mathrm{NaOH}(\mathrm{pH}$ 9.0-11.0). The reaction was performed by pre-incubating the enzyme in above buffers at $37^{\circ} \mathrm{C}$ for $24 \mathrm{~h}$ and then the residual activities with $p$ NPP as substrate were followed to assay. The experiments were repeated in triplicate.

\section{Effect of Metal Ions on Enzyme Activity}

The effect of metal ions $\left(\mathrm{Mn}^{2+}, \mathrm{Fe}^{2+}, \mathrm{Mg}^{2+}, \mathrm{Ca}^{2+}\right.$, $\mathrm{Zn}^{2+}, \mathrm{Cu}^{2+}, \mathrm{Ni}^{2+}$ and $\mathrm{Ba}^{2+}$ ) or chelator (EDTA) on the recombinant lipase Lu10-1 activity was performed as follows: $5 \mathrm{nM}$ purified enzyme was pre-incubated with each above metal ion at a concentration of $1 \mathrm{mM}$ in Tris$\mathrm{HCl}$ buffer $(50 \mathrm{mM}, \mathrm{pH} 8.0)$ at $37^{\circ} \mathrm{C}$ for $30 \mathrm{~min}$ and then measured for residual activity against $p$ NPP. Enzyme activity without metal ion added was defined as $100 \%$. The experiments were repeated in triplicate.

\section{Effect of Surfactants on Enzyme Activity}

The effects of various surfactants [Triton X-100, Tween 20, Tween 80, SDS and sodium taurodeoxycholate (TDOC)] at different concentrations on the recombinant lipase Lu10-1 were investigated by adding $5 \mathrm{nM}$ purified enzyme to Tris- $\mathrm{HCl}$ buffer $(50$
$\mathrm{mM}, \mathrm{pH}$ 9) with each surfactant at a concentration of 1 $\mathrm{mM}$ or $10 \mathrm{mM}$ and the solution was pre-incubated at $37^{\circ} \mathrm{C}$ for $30 \mathrm{~min}$ and then assayed for residual activity against $p$ NPP. Enzyme activity without added surfactants was defined as $100 \%$. The experiments were repeated in triplicate.

\section{Stability in Organic Solvent}

The stabilities of the recombinant lipase Lu10-1 in different organic solvents (methanol, ethanol, isopropyl alcohol, butanol, acetone, n-hexane, benzene, amyl alcohol and dimethyl sulfoxide) were tested in a Tris$\mathrm{HCl}$ buffer $(50 \mathrm{mM}, \mathrm{pH} 9)$ containing $75 \%$ (v/v) of each solvent and $5 \mathrm{nM}$ purified enzyme. After $18 \mathrm{~h}$ of incubation at $20^{\circ} \mathrm{C}$, aliquots were removed for determination of residual activity against $p$ NPP. Enzyme activity without organic solvents was defined as the $100 \%$ level. The experiments were repeated in triplicate.

\section{Results and Discussion}

\section{Cloning, Expression and Purification of Lipase Lu} 10-1 in E. coli

The gene of lipase Lu10-1 excluding the signal peptide fragment of 44 amino acids (Fig. 1) was cloned from the total DNA of $B$. cepacia Lu10-1 and heterologously over-expressed for further characterization. Nucleotide sequence analysis indicated that this lipase gene length was 960 bp for encoding a mature protein consisting of 320 amino acids. Most mature lipase included the conserved penta-peptide motif (Gly-His-Ser-Gln-Gly) with an active serine residue (Ser 87). Additionally, a catalytic center formed by Ser 87, Asp 264 and His 286, as shown in these Burkholderia sp. lipases (Kim et al., 1997; Wang et al., 2009). Multiple sequence alignment showed that lipase Lu10-1 shared $99.8 \%$ homology of nucleotide sequence and 100\% homology of amino acid sequence with that of Burkholderia sp. MC16-3 and B. cepacia G63 (Fig. 1). However, lipase Lu10-1 showed three residues (172 T/A, $194 \mathrm{~A} / \mathrm{T}, 355 \mathrm{R} / \mathrm{H})$ difference with that of $\mathrm{B}$. cepacia 25416, which might be one of the reasons for exhibiting different biochemical properties.

The cloned gene described above was followed by insertion into the expression vector pET20b(+), encoding an N-terminal signal peptide PelB and a C-terminal $\mathrm{His}_{6}$ tag to allow the heterologously over-expressed lipase to be secreted. The resulting construct pET20b/lip was expressed in E. coli BL21 (DE3). After culturing for 48 $\mathrm{h}$, the amount of lipase produced from the recombinant strain could reach the activity of $19 \mathrm{U} / \mathrm{mL}$ for the culture supernatant and $28 \mathrm{U} / \mathrm{mL}$ for the cell lysates with $p$-NPP as substrate respectively, meanwhile no enzyme activity 
was detected in the control strain [harboring the empty plasmid pET20b $(+)$ ]. However, the extracellular activity was much lower than currently used lipases $(142 \mathrm{U} / \mathrm{mL})$ from B. cepacia (Wang et al., 2009). Due to significant expression of lipase gene concentrated in the form of inclusion bodies in $E$. coli cell pellets (Fig. 2), appropriate strategies to improve the extracellular secretion need further investigation. The extracellular recombinant enzyme was purified to homogeneity simply by one-step nickel affinity chromatography and showed a specific activity of 139 $\mathrm{U} / \mathrm{mg}$ for lipase Lu10-1 (Table 1). A 4.8-fold purification with $25 \%$ recovery was approximately achieved. SDS-PAGE analysis demonstrated that the recombinant lipase Lu10-1 exhibited the apparent molecular mass of $\sim 33 \mathrm{kDa}$ (Fig. 2), which was consistent with lipases from other Burkholderia sp. with estimated molecular weights of 29-35 kDa (Dalal et al., 2008; Wang et al., 2009; Xie et al., 2016; Yang et al., 2007; Yao et al., 2013).

\section{Substrate Specificity}

Previous researches have shown that many lipases are provided with broad substrate specificity against soluble ester and insoluble triglycerides (Fickers et al., 2011; Jaeger et al., 1999; Singh and Mukhopadhyay, 2012). Subsequently, the lipase specificity towards the chain length of esters was considered using $p$-nitrophenyl-fatty acyl esters and triglycerides (Table 2). For lipase Lu10-1, its activity against the $\mathrm{C} 16 p$-nitrophenyl-fatty acid ester $p$ NPP was significantly increased by 1.78 fold than that towards the corresponding $\mathrm{C} 4$ ester $p$ NPB. Similarly, its activity against the $\mathrm{C} 18$ ester triolein was also improved by 1.4 fold than that of the corresponding $\mathrm{C} 4$ triglyceride tributyrin. Therefore, a trend of preferential specificity towards longer chain length substrates is obviously evident. Most lipases, especially from Burkholderia sp. prefer medium- or longchain fatty acid esters in previous study (Patel et al., 2014; Wang et al., 2009; Xie et al., 2016; Yao et al., 2013), which was consistent with our findings.

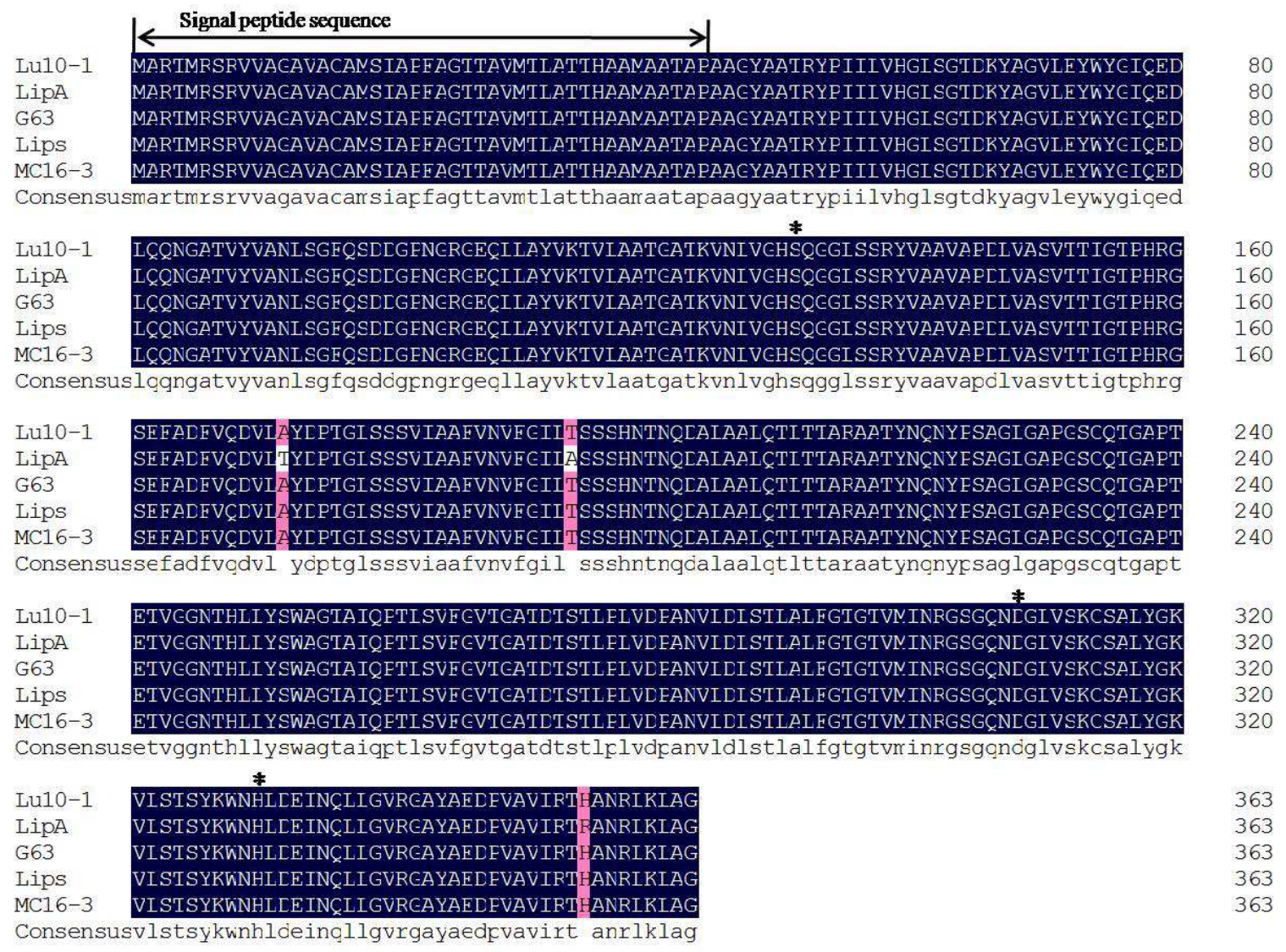

Fig. 1: Multiple alignment of amino acid sequences of lipase Lu10-1 with several other lipases. Abbreviations and accession numbers of lipases are as follows: lipase Lu10-1 from B. cepacia Lu10-1, lipase LipA from B. cepacia ATCC 25416 (accession no. ADT80785.1), lipase G63 from B. cepacia G63 (accession no. ABN09945.1), lipase MC16-3 from Burkholderia sp. MC16-3 (accession no. AAV34203.1), lipase Lips from B. cepacia (accession no. WP027791104.1). active-site residues are indicated by stars $(*)$ 


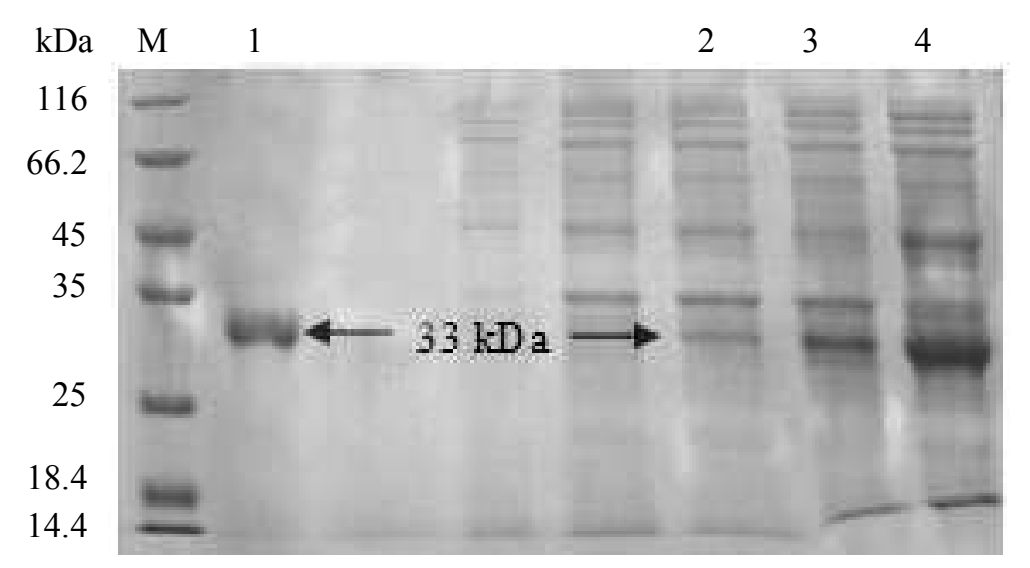

Fig. 2: SDS-PAGE analysis of over-expressed and purified lipase Lu10-1. Lane M, molecular mass marker; lane 1, purified lipase Lu10-1; lane 2, culture supernatant of E.coli BL21(DE3)/pET20b/lip; lane 3, cell lysate of E.coli BL21(DE3)/pET20b/lip; lane 4, cell inclusion body of E.coli BL21(DE3)/pET20b/lip

Table 1: Purification of recombinant lipase Lu10-1 from E. coli BL21(DE3)

\begin{tabular}{lccccc}
\hline Purification step & $\begin{array}{l}\text { Total protein } \\
(\mathrm{mg})\end{array}$ & $\begin{array}{l}\text { Total activity } \\
(\mathrm{U})\end{array}$ & $\begin{array}{l}\text { Specific activity } \\
(\mathrm{U} / \mathrm{mg} \text { protein) }\end{array}$ & $\begin{array}{l}\text { Yield } \\
(\%)\end{array}$ & $\begin{array}{l}\text { Purification } \\
\text { (fold) }\end{array}$ \\
\hline Crude extract & 664 & 19511 & 29 & 100.0 & 1.0 \\
Ammonium sulfate fraction & 182 & 11629 & 64 & 60 & 2.2 \\
Ni-Sepharose affinity purification & 35 & 4852 & 139 & 25 & 4.8 \\
\hline
\end{tabular}

Note: The enzymatic activity was assayed using $p$ NPP as substrate

Table 2: Specificity of lipase Lu10-1 towards the acyl chain length of different esters

\begin{tabular}{ll}
\hline Substrate & Specificity activity $(\mathrm{U} / \mathrm{mg})$ \\
\hline$p$ NPB & $78 \pm 11$ \\
$p$ NPP & $139 \pm 8$ \\
tributyrin & $91 \pm 5$ \\
triolein & $124 \pm 4$
\end{tabular}

Note: Specificity of lipase Lu10-1was determined at its optimal temperature of $60^{\circ} \mathrm{C}$. Values are means $\pm \mathrm{SD}(\mathrm{n}=3)$

Effect of Temperature and $p H$ on Activity and Stability of Lipase Lu10-1

Generally in biodiesel production or other high temperature industries, high temperature $\left(>40^{\circ} \mathrm{C}\right)$ could increase the diffusion and miscibility in different phases and thereby improve the conversion efficiency. In this study, the influence of temperature on the enzyme activity was investigated with a range from 35 to $80^{\circ} \mathrm{C}$ at $\mathrm{pH} 8.0$ (Fig. 3). The optimum temperature curve of lipase Lu10-1 exhibited that the enzyme activity improved followed with increasing temperature from 35 to $60^{\circ} \mathrm{C}$ and decreased from 60 to $80^{\circ} \mathrm{C}$ and it retained nearly $80 \%$ residual activity at $70^{\circ} \mathrm{C}$ (Fig. 3A). The activity at the optimum temperature of $60^{\circ} \mathrm{C}$ was 5 -fold higher than that at $35^{\circ} \mathrm{C}$. However, most lipases from fungi or bacterium had an optimum temperature at $40-45^{\circ} \mathrm{C}$ (Dalal et al., 2008; Fickers et al., 2011; Sun et al., 2016; Xie et al., 2016). Of course, a small number of lipases could reach an optimal temperature of $60^{\circ} \mathrm{C}$ (Wang et al., 2009; Yao et al., 2013). The thermostable experiment showed that lipase Lu10-1 preserved high thermostability, with residual activities of over $80 \%$ after $100 \mathrm{~h}$ at $60^{\circ} \mathrm{C}$ or over $60 \%$ after $30 \mathrm{~h}$ at $70^{\circ} \mathrm{C}$ (Fig. 3B), while lipases reported from other $B$. cepacia strains, such as ATCC25609 or RQ3 pocessed lower stability below $50^{\circ} \mathrm{C}$ with a half-life of less than $1 \mathrm{~h}$ (Dalal et al., 2008; Xie et al., 2016).

The $\mathrm{pH}$ optimum and stability of lipase Lu10-1 were measured at a $\mathrm{pH}$ range of 5.0-11.0 (Fig. 3). The lipase Lu10-1 displayed comparatively high activity under alkaline conditions and performed an optimum $\mathrm{pH}$ of 9.0 (Fig. 3C). The enzyme was considerably stable with a broad $\mathrm{pH}$ range from 5.0 to 10.0 and retained more than $80 \%$ of its initial activity at $\mathrm{pH} 6.0-9.0$ after incubation at $37^{\circ} \mathrm{C}$ for $24 \mathrm{~h}$ (Fig. 3D). Most microbial lipases displayed narrow $\mathrm{pH}$ stabilities, for example, the lipases from B. cepacia ATCC25609 and LP08 were merely stable at $\mathrm{pH}$ 9.0-10.0 and $\mathrm{pH}$ 8.0-9.0, respectively (Dalal et al., 2008; Wang et al., 2009). Obviously, lipase Lu10-1 showed a stable performance across a wide $\mathrm{pH}$ range, which would be advantageous to its application in complex and diverse industrial environments.

\section{Metal ion Requirement}

According to previous reports, most lipases from B. cepacia and other Burkholder sp. required the presence of metal ions to fully exert their activity (Kim et al., 2001). The requirement of metal cofactor for lipase Lu10-1 was performed by incubating the enzyme with the metal ions or metal chelator EDTA and then assayed for activity against $p$ NPP (Table 3 ). 

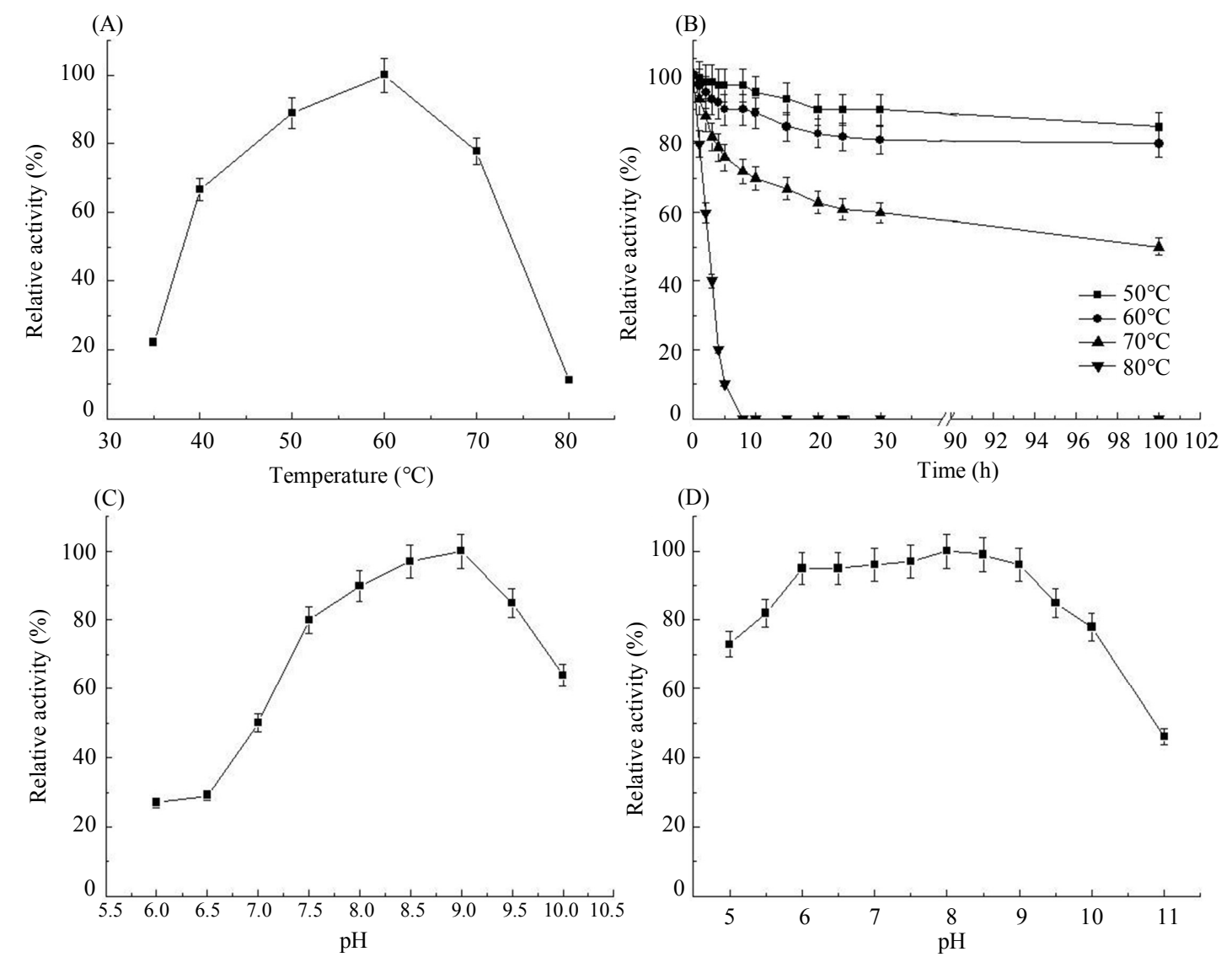

Fig. 3: Effects of $\mathrm{pH}$ and temperature on activity and stability of lipase Lu10-1. over Temperature optimum. The samples were determined in Tris- $\mathrm{HCl}(\mathrm{pH} 9.0)$. The activity of lipase Lu10-1 at $60^{\circ} \mathrm{C}$ as $100 \%$. (B) Thermostability. The stability of the enzymes were performed in Tris- $\mathrm{HCl}(\mathrm{pH} 9.0)$ at $50^{\circ} \mathrm{C}(\boldsymbol{\bullet}), 60^{\circ} \mathrm{C}(\bullet), 70^{\circ} \mathrm{C}(\boldsymbol{\Delta})$ and $80^{\circ} \mathrm{C}(\boldsymbol{\nabla})$. The activity of lipase Lu101 without heat treated was defined as $100 \%$. (C) $\mathrm{pH}$ optimum. The samples were determined in the following bufferpotassium phospate ( $\mathrm{pH} 6.0-7.0)$, Tris- $\mathrm{HCl}$ (7.0-9.0) and sodium carbonate ( $\mathrm{pH} 9.0-10.0)$. The activity of lipase Lu10-1 at $\mathrm{pH} 9.0$ was defined as $100 \%$. (D) $\mathrm{pH}$ stability. The enzyme activity was determined after incubation $24 \mathrm{~h}$ at $37^{\circ} \mathrm{C}$ in the following buffers- sodium acetate $(\mathrm{pH} 4.0-6.0)$, potassium phospate $(\mathrm{pH} 6.0-7.0)$, Tris- $\mathrm{HCl}(\mathrm{pH} 7.0-9.0)$ and glycine- $\mathrm{NaOH}$ (pH 9.0-11.0). The activity of lipase Lu10-1 at pH 9.0 was defined as 100\%. All activity were performed in triplicate. Error bars correspond to the standard deviation of three independent determinations

Table 3: Effect of metal ions and metal chelator on lipase Lu10-1 activity

\begin{tabular}{llll}
\hline Metal ions/Metal chelator & Relative activity (\%) & Metal ions/Metal chelator & Relative activity (\%) \\
\hline Control & $100 \pm 5$ & $\mathrm{Zn}^{2+}$ & $85 \pm 5$ \\
$\mathrm{Mn}^{2+}$ & $67 \pm 4$ & $\mathrm{Cu}^{2+}$ & $96 \pm 5$ \\
$\mathrm{Fe}^{2+}$ & $78 \pm 5$ & $\mathrm{Ni}^{2+}$ & $101 \pm 5$ \\
$\mathrm{Mg}^{2+}$ & $94 \pm 4$ & $\mathrm{Ba}^{2+}$ & $92 \pm 3$ \\
$\mathrm{Ca}^{2+}$ & $118 \pm 7$ & EDTA & $89 \pm 4$ \\
\hline
\end{tabular}

Note: The lipase Lu10-1 was pre-incubated with metal ions or metal chelator $(1 \mathrm{mM})$ at $37^{\circ} \mathrm{C}$ for 30 min and then assayed for lipase activity using $p$ NPP as substrate. Values are means $\pm \mathrm{SD}(\mathrm{n}=3)$

Among the tested metal ions, $\mathrm{Ca}^{2+}, \mathrm{Mg}^{2+}, \mathrm{Cu}^{2+}, \mathrm{Ni}^{2+}$ and $\mathrm{Ba}^{2+}$ did not exhibit a significant influence on the enzyme activity, whereas $\mathrm{Mn}^{2+}, \mathrm{Fe}^{2+}$ and $\mathrm{Zn}^{2+}$ with remaining only 67,78 and $85 \%$ of activities, respectively, showed a medium inhibitory effect. According to previous report, the calcium-binding site was well conserved (Kim et al., 2001) in the crystal structures of lipases from B. cepacia and other species. Many lipases have been reported to display significantly enhanced activity (increased 2-3 fold) in the presence of $\mathrm{Ca}^{2+}$ (Wang et al., 2009; Xie et al., 2016), but this stimulation by $\mathrm{Ca}^{2+}$ was not obviously found in our study. The metal chelator EDTA exhibited a little effect on the enzyme activity, which was consistent with the 
results of lipase from Pseudomonas stutzeri LC2-8 (Cao et al., 2012) and Burkholderia ambifaria YCJ01 (Yao et al., 2013). It might be suggesting that lipase Lu10-1 did not require divalent cations for its activity.

\section{Lipase Stability Towards Surfactants}

Application of industrial enzymes often involves relatively harsh conditions such as the presence of surfactants and organic solvents. The activity of lipase Lu10-1 was tested in the presence of the nonionic surfactants Triton X-100, Tween 20, Tween 80 and anionic surfactants SDS and TDOC (Table 4). At concentrations of $1 \mathrm{mM}$ and $10 \mathrm{mM}$, Triton X-100, Tween 20, Tween 80 and SDS did not significantly reduce enzyme activity. The effect of TDOC was only one exception because it stimulated the activity of lipase Lu10-1 with a $9 \%$ increase at $1 \mathrm{mM}$ and a $29 \%$ increase at $10 \mathrm{mM}$ after incubation for $30 \mathrm{~min}$ at $37^{\circ} \mathrm{C}$. TDOC is an anionic surfactant with a bulky side chain which might bind to the hydrophobic sites of proteins preventing their aggregation and rendering them more stable (Creveld et al., 2001).

\section{Organic Solvent Stability of Lipase Lu10-1}

Lipases have been reported to show esterification and transesterification activity and have potential use in bioconversion industry (Jaeger et al., 1999; Sasso et al., 2016; Yang et al., 2007). Such applications often involve the use of organic phase, therefory, the activity and stability in organic solvents are identified as novel feature for lipase. Influences of different organic solvents with a concentration of $75 \%$ on the stability of lipase Lu10-1 were studied by incubating enzyme solution after incubated for $18 \mathrm{~h}$ at $20^{\circ} \mathrm{C}$. As shown in Table 5, there was not significant effect on the activity of lipase Lu10-1 in methanol, ethanol, n-hexane, benzene and dimethyl sulfoxide. Among of all the tested organic solvents, lipase Lu10-1 exhibited a high tolerance in amyl alcohol, with the remaining activity of $92 \%$. However, the endurance of lipase Lu10-1 to isopropyl alcohol, butanol and acetone is restricted to some extent and the remaining activity was 57,43 and $75 \%$, respectively. Despite the reported solvent stability for other lipases with a usual concentration for organic solvents of only $50 \%$ or less (Wang et al., 2009; Yang et al., 2007) and most lipases were still inhibited by organic solvents like ethanol, methanol and isopropanol. Result from our study showed that lipase Lu10-1 is able to be tolerate to a higher concentration $(75 \%)$ of organic solvent used in biodiesel production. The structurefunction relationship about the solvent tolerance of this lipase could be provided for further research. The obvious stability of lipase Lu10-1 towards organic solvents made it ideal for applying as a biocatalyst in non-aqueous media.
Table 4: Effect of surfactants on lipase Lu10-1 activity

\begin{tabular}{lll}
\hline & Relative activity (\%) & \\
Surfactants & ------- \\
Concentration & $1 \mathrm{mM}$ & $10 \mathrm{mM}$ \\
\hline Triton X-100 & $88 \pm 4$ & $84 \pm 4$ \\
Tween 20 & $60 \pm 3$ & $53 \pm 3$ \\
Tween 80 & $74 \pm 4$ & $72 \pm 4$ \\
SDS & $85 \pm 4$ & $84 \pm 4$ \\
TDOC & $109 \pm 5$ & $129 \pm 6$
\end{tabular}

Note: The lipase Lu10-1 was pre-incubated with the surfactant at $37^{\circ} \mathrm{C}$ for $30 \mathrm{~min}$ and then assayed for lipase activity using $p \mathrm{NPP}$ as substrate. Values are means $\pm \mathrm{SD}(\mathrm{n}=3)$

Table 5: Stability of lipase Lu10-1 in organic solvents

\begin{tabular}{llll}
\hline Organic solvents & $\begin{array}{l}\text { Relative } \\
\text { activity (\%) }\end{array}$ & $\begin{array}{l}\text { Organic } \\
\text { solvents }\end{array}$ & $\begin{array}{l}\text { Relative } \\
\text { activity (\%) }\end{array}$ \\
\hline Control & $100 \pm 3$ & Acetone & $75 \pm 4$ \\
Methanol & $84 \pm 4$ & n-Hexane & $85 \pm 4$ \\
Ethanol & $89 \pm 4$ & Benzene & $82 \pm 4$ \\
Isopropyl alcohol & $57 \pm 3$ & Amyl alcohol & $92 \pm 3$ \\
Butanol & $43 \pm 2$ & Dimethyl sulfoxide & $89 \pm 4$ \\
\hline
\end{tabular}

Note: The lipase Lu10-1 was preincubated with $75 \%(\mathrm{v} / \mathrm{v})$ of organic solvents in assay buffer at $20^{\circ} \mathrm{C}$ for $18 \mathrm{~h}$. Aliquots were removed for determination of residual activity. Values are means $\pm \operatorname{SD}(\mathrm{n}=3)$

\section{Conclusion}

In summary, the lipase from $B$. cepacia Lu10-1 was cloned, heterologously over-expressed and its biochemical properties were investigated in detail. The purified recombinant lipase $\mathrm{Lu} \mathrm{10-1}$ pocessed maximum activity at $60^{\circ} \mathrm{C}$ and $\mathrm{pH} 9.0$, had excellent thermostability (remaining over $80 \%$ activity after $100 \mathrm{~h}$ at $60^{\circ} \mathrm{C}$ or over $60 \%$ after $30 \mathrm{~h}$ at $70^{\circ} \mathrm{C}$ ) and broad $\mathrm{pH}$ adaptability (retaining $80 \%$ activity between $\mathrm{pH} 6.0$ and 9.0 after incubation at $37^{\circ} \mathrm{C}$ for $24 \mathrm{~h}$ ) and was highly tolerant and stable to kinds of surfactants and organic solvents. Thus, the lipase Lu10-1 with above distinct properties possesses development prospects in basic research and various industrial applications.

\section{Funding Information}

This work was supported by the National Natural Science Foundation of China (31670064, 31271812), Taishan Industry Leading Talent Project (LJNY201606), Science and Technology Project of Shandong College (J16LE20), China Postdoctoral Science Foundation (2017M612305, 2015T80735), Zibo City and University Integration Project (2017ZBXC214 and 2017ZBXC169), Doctor and Postdoctoral Foundation of Shandong University of Technology (4041/415047, 4041/516002).

\section{Author's Contributions}

Yao Zhang: Has contributed in a whole experiment, data analysis and publication. 
Lu Wang: Has assisted in the experiment.

Yuanda Song: Has reviewed and revised the manuscript.

\section{Ethics}

All authors read and approved the final version of this manuscript. There are not any ethical issues to declare that could arise after the publication of this manuscript.

\section{References}

Cao, Y., Y. Zhuang, C.J. Yao, B. Wu and B. F. He, 2012. Purification and characterization of an organic solvent-stable lipase from Pseudomonas stutzeri LC2-8 and its application for efficient resolution of (R, S)-1-phenylethanol. Biochem. Eng. J., 64: 55-60. DOI: 10.1016/j.bej.2012.03.004

Chen, S., X. Tong, R. W. Woodard, G. Du and J. Wu, 2008. Identification and characterization of bacterial cutinase. J. Biol. Chem., 283: 25854-25862. DOI: $10.1074 /$ jbc.M800848200

Creveld, L.D., W. Meijberg, H.J. Berendsen and H.A. Pepermans, 2001. DSC studies of Fusarium solani pisi cutinase: consequences for stability in the presence of surfactants. Biophys. Chem., 92: 65-75. DOI: S0301-4622(01)00187-9

Dalal, S., P. K. Singh, S. Raghava, S. Rawat and M.N. Gupta, 2008. Purification and properties of the alkaline lipase from Burkholderia cepacia A.T.C.C. 25609. Biotechnol. Applied Biochem., 51: 23-31. DOI: 10.1042/BA20070186

Fickers, P., A. Marty and J.M. Nicaud, 2011. The lipases from Yarrowia lipolytica: genetics, production, regulation, biochemical characterization and biotechnological applications. Biotechnol. Adv., 29: 632-644. DOI: 10.1016/j.biotechadv.2011.04.005

Garcia-Silvera, E.E., F. Martinez-Morales, B. Bertrand, D. Morales-Guzman and N.S. Rosas-Galvan, 2017. Production and application of a thermostable lipase from Serratia marcescens in detergent formulation and biodiesel production. Biotechnol. Applied Biochem. DOI: 10.1002/bab. 1565

Gricajeva, A., V. Bendikiene and L. Kalediene, 2016. Lipase of Bacillus stratosphericus L1: Cloning, expression and characterization. Int. J. Biol. Macromol., 92: 96-104.

DOI: 10.1016/j.ijbiomac.2016.07.015

Jaeger, K.E., B.W. Dijkstra and M.T. Reetz, 1999. Bacterial biocatalysts: Molecular biology, threedimensional structures and biotechnological applications of lipases. Ann. Rev. Microbiol., 53: 315-351. DOI: 10.1146/annurev.micro.53.1.315

Jaeger, K.E., S. Ransac, B.W. Dijkstra, C. Colson and M. van Heuvel, 1994. Bacterial lipases. FEMS Microbiol. Rev., 15: 29-63.
Ji, X., G. Lu, Y. Gai, H. Gao and B. Lu, 2010. Colonization of Morus alba L. by the plant-growthpromoting and antagonistic bacterium Burkholderia cepacia strain Lu10-1. BMC Microbiol., 10: 243-254. DOI: 10.1186/1471-2180-10-243

Jia, B., J.K. Yang, W.S. Liu, X. Li and Y.J. Yan, 2010. Homologous overexpression of a lipase from Burkholderia cepacia using the lambda Red recombinase system. Biotechnol. Lett., 32: 521-526. DOI: 10.1007/s10529-009-0189-9

Kim, E.K., W.H. Jang, J.H. Ko, J.S. Kang and M.J. Noh, 2001. Lipase and its modulator from Pseudomonas sp. strain KFCC 10818: proline-to-glutamine substitution at position 112 induces formation of enzymatically active lipase in the absence of the modulator. J. Bacteriol., 183: 5937-5941. DOI: $10.1128 / J B .183 .20 .5937-5941.2001$

Kim, K.K., H.K. Song, D.H. Shin, K.Y. Hwang and S.W. Suh, 1997. The crystal structure of a triacylglycerol lipase from Pseudomonas cepacia reveals a highly open conformation in the absence of a bound inhibitor. Structure, 5: 173-185. DOI: S0969-2126(97)00177-9

Mello Bueno, P.R., T.F. de Oliveira, G.L. Castiglioni, M.S. Soares Junior and C.J. Ulhoa, 2015. Application of lipase from Burkholderia cepacia in the degradation of agro-industrial effluent. Water Sci. Technol., 71: 957-964. DOI: 10.2166/wst.2015.037

Patel, V., S. Nambiar and D. Madamwar, 2014. An extracellular solvent stable alkaline lipase from Pseudomonas sp. DMVR46: partial purification, characterization and application in non-aqueous environment. Process Biochem., 49: 1673-1681. DOI: $10.1016 /$ j.procbio.2014.06.007

Sangeetha, R., I. Arulpandi and A. Geetha, 2011. Bacterial lipases as potential industrial biocatalysts: An overview. Res. J. Microbiol., 6: 1-24.

Sasso, F., A. Natalello, S. Castoldi, M. Lotti and C. Santambrogio, 2016. Burkholderia cepacia lipase is a promising biocatalyst for biofuel production. Biotechnol. J., 11: 954-960. DOI: $10.1002 /$ biot. 201500305

Shu, Z., H. Lin, S. Shi, X. Mu and Y. Liu, 2016. Cellbound lipases from Burkholderia sp. ZYB002: Gene sequence analysis, expression, enzymatic characterization and $3 \mathrm{D}$ structural model. BMC Biotechnol., 16: 38-38.

DOI: $10.1186 / \mathrm{s} 12896-016-0269-6$

Singh, A.K. and M. Mukhopadhyay, 2012. Overview of fungal lipase: A review. Applied Biochem. Biotechnol., 166: 486-520. DOI: $10.1007 / \mathrm{s} 12010-011-9444-3$

Sun, Q., H. Wang, H. Zhang, H. Luo and P. Shi, 2016. Heterologous production of an acidic thermostable lipase with broad-range $\mathrm{pH}$ activity from thermophilic fungus Neosartorya fischeri P1. J. Biosci. Bioeng., 122: 539-544. DOI: 10.1016/j.jbiosc.2016.05.003 
Wang, H.K., R.J. Liu, F.P. Lu, W. Qi and J. Shao, 2009. A novel alkaline and low-temperature lipase of Burkholderia cepacia isolated from Bohai in china for detergent formulation. Ann. Microbiol., 59: 105-110.

Wang, X., X. Yu and Y. Xu, 2009. Homologous expression, purification and characterization of a novel high-alkaline and thermal stable lipase from Burkholderia cepacia ATCC 25416. Enzyme Microb. Technol., 45: 94-102.

DOI: $10.1016 /$ j.enzmictec.2009.05.004

Xie, C., B. Wu, S. Qin and B. He, 2016. A lipase with broad solvent stability from Burkholderia cepacia RQ3: isolation, characteristics and application for chiral resolution of 1-phenylethanol. Biopro. Biosyst. Eng., 39: 59-66.

DOI: $10.1007 /$ s00449-015-1489-1
Yang, J., D. Guo and Y. Yan, 2007. Cloning, expression and characterization of a novel thermal stable and short-chain alcohol tolerant lipase from Burkholderia cepacia strain G63. J. Mol. Catal. B Enzym., 45: 91-96.

DOI: $10.1016 /$ j.molcatb.2006.12.007

Yao, C.J., Y. Cao, S.S. Wu, S. Li and B.F. He, 2013. An organic solvent and thermally stable lipase from Burkholderia ambifaria YCJ01: purification, characteristics and application for chiral resolution of mandelic acid. J. Mol. Catal. B Enzym, 85: 105-110.

Zhang, Y., S. Chen, M. Xu, A. Cavaco-Paulo and J. $\mathrm{Wu}, 2010$. Characterization of Thermobifida fusca cutinase-carbohydrate-binding module fusion proteins and their potential application in bioscouring. Applied Environ. Microbiol., 76: 6870-6876. DOI: 10.1128/AEM.00896-10 